\title{
EDUCAÇÃO À DISTÂNCIA E A VALORIZAÇÃO DA ENFERMAGEM
}

\author{
Elizabeth Bernardino ${ }^{1}$
}

Em 17 de maio de 2016, eventos realizados em todo país marcaram o Dia de Luta pela Valorização da Enfermagem. A PL 2295/2000 que dispõe sobre as 30 horas, a instituição do piso salarial profissional, condições de trabalho e a oferta de cursos de graduação, na modalidade de Educação à Distância, foram alguns dos temas que permearam as discussões, articuladas pelas entidades representativas da Enfermagem Brasileira, em diferentes fóruns.

Hierarquizar esses temas seria injusto e improcedente face às lutas históricas da categoria, no entanto, as mais de 50 mil vagas de graduação à distância colocaram este assunto na agenda de docentes e coordenadores de Cursos de Graduação em Enfermagem.Que profissionais precisamos formar? Quem nós gostaríamos que nos atendessem e a nossos filhos nos momentos de fragilidade? Será que o aprendizado do cuidado técnico e humano pode se dar apenas por tecnologias digitais? Será que as plataformas virtuais conseguem substituir o "pegar na mão", o ensinar de um professor dedicado? Como ensinar as sutilezas do cuidar profissional?

Tantas indagações se somam aos inúmeros desafios impostos pelo envelhecimento da população, aumento de doenças crônicas, recrudescimento de doenças infecciosas e oportunistas, epidemias, alto impacto tecnológico na saúde se contrapondo às necessidades de acolhimento, de acesso e de continuidade da atenção.

A Educação à Distância tem sido utilizada, no exterior e no Brasil, para expandir o acesso aos cursos de nível superior, aperfeiçoamento profissional, educação permanente e como ferramenta pedagógica. No que concerne à Enfermagem, a Educação à Distância deve ser usada de forma complementar. $\mathrm{O}$ uso de ambientes virtuais é muito interessante e pode ser um diferencial. Nos processos de ensino e aprendizagem, as atividades são desenvolvidas em lugares ou tempos diversos, e contribuem para desenvolvimento da autonomia, flexibilidade e criatividade mediadas pelo docente e o tutor. Nesse caso, alunos e professores são chamados a rever seus papéis em uma perspectiva mais de colaboração do que de subordinação, é um grande aprendizado.

A graduação em enfermagem, inteiramente à distância, tem sido vista com temeridade, menos porque retrata a ignorância, em termos de formação, dos investidores privados da educação, mas porque, o cuidar profissional envolve conhecimentos distintos, técnico, científico, tecnológico, ético e humanista, com grande implicação no resultado final da saúde das pessoas (profissionais e usuários), seja com ações de promoção, prevenção e recuperação.

Um sopro de esperança veio com iniciativas concretas; o decreto $n^{\circ}$ 8754, de 10 de maio de 2016, que institui a obrigatoriedade de manifestação do Conselho Nacional de Saúde, antes da decisão do Ministério da Educação, sobre a autorização de criação de Cursos de Enfermagem, resultado de um esforço da Associação Brasileira de Enfermagem. Outra é o Projeto de Lei 2.891/2015, que proíbe a formação de enfermeiros e técnicos de Enfermagem na modalidade não-presencial e que já recebeu parecer favorável da Comissão de Educação, e; mais recentemente, em 02 de junho de 2016, a aprovação, pelo plenário do Conselho Nacional de Saúde, a proibição de cursos de graduação e formação técnica a distância na área de Saúde de todo o Brasil.

Diante dos fatos, cabe ressaltar que a natureza da profissão impõe certas condições que inclui número expressivo de horas em práticas e estágios,pois enfermeiros e enfermeiras não podem ser formados à distância e o uso desta estratégia, de forma correta e complementar, pelas escolas formadoras, expressa o compromisso e a responsabilidade para com a sociedade a que servimos.

${ }^{1}$ Enfermeira. Doutora em Enfermagem. Docente da Universidade Federal do Paraná. Coordenadora do Curso de Graduação e Licenciatura em Enfermagem. 